Int. J. Electrochem. Sci., 14 (2019) 6337 - 6346

\title{
Designing an Electrochemical System for Efficient Removal of Chromium from Leachate by Electrocoagulation Using a Solar Panel as the Power Supply
}

\author{
Mostafa Mohammadi zaroun, Abdollah Yari ${ }^{*}$ \\ Department of Chemistry, Faculty of Science, Lorestan University 681781733 Khorramabad-Iran \\ *E-mail: a.yari@ymail.com, yari.a@lu.ac.ir
}

doi: $10.20964 / 2019.07 .57$

Received: 8 March 2019 / Accepted: 10 May 2019 / Published: 10 June 2019

\begin{abstract}
Here, we report the removal of chromium from landfill leachate by electrocoagulation (EC) using iron and aluminum electrodes and a solar panel as the electrical energy source. Two rectangular plates of aluminum and iron were used as cathode and anode, respectively. Different kinds of operational parameters such as contact time, $\mathrm{pH}$, inter-electrode distance and current density were investigated and optimized to obtain the best process function. Based on the findings, the removal efficiency of chromium increased by increasing the current density and the reaction time and decreasing the distance between the electrodes. The experimental results indicated that the removal efficiency of chromium of $98.0 \%$ from raw leachate was obtained under the optimized conditions of current density $4.5 \mathrm{~A} / \mathrm{m}^{2}$, initial $\mathrm{pH}$ of 3, contact times $27.0 \mathrm{~min}$ and the electrode-distance of $0.5 \mathrm{~cm}$.
\end{abstract}

Keywords: electrochemical system; electrocoagulation; raw leachate; chromium; iron and aluminum electrodes

\section{$\underline{\text { FULL TEXT }}$}

(C) 2019 The Authors. Published by ESG (www.electrochemsci.org). This article is an open access article distributed under the terms and conditions of the Creative Commons Attribution license (http://creativecommons.org/licenses/by/4.0/). 